\title{
Intra-abdominal follicular lymphoma masquerading as severe cardiopulmonary disease in a Vietnam War veteran exposed to agent orange
}

\author{
Michael S Lundin, ${ }^{\oplus 1,2}$ Calvin Abro, $^{2}$ Heather Laird-Fick ${ }^{2}$
}

'Department of Internal Medicine, Michigan State University College of Human Medicine, East Lansing, Michigan, USA ${ }^{2}$ Sparrow Hospital, Lansing, Michigan, USA

Correspondence to Dr Michael S Lundin, lundinmi@msu.edu

Accepted 13 March 2019

\section{DESCRIPTION}

A 68-year-old Hispanic male US Army veteran with a medical history of chronic obstructive lung disease, undefined lung scarring, heart failure with preserved ejection fraction, obstructive sleep apnoea, obesity hypoventilation syndrome [on oxygen by nasal cannula $2-4 \mathrm{~L}$, bilevel positive airway pressure (BiPAP) at night] and diabetes mellitus type II, presented to the hospital with dyspnoea and was initiated on treatment for heart failure. The patient had served as an artilleryman in the Vietnam War and had been exposed to Agent Orange-a herbicide used in the US military for defoliation for 10 years prior to discovery of it causing birth defects in laboratory animals. A few studies have not shown that it causes malignancies, ${ }^{1}$ but the latest consensus and summary of evidence is that it has been associated with malignancies. ${ }^{2}$

One month prior to this presentation, the patient was hospitalised for 1 week after experiencing respiratory failure thought to be due to an exacerbation of his heart failure and an upper respiratory tract infection. Within a few weeks after discharge, however, he again started feeling short of breath and gained weight despite doubling his home dose of furosemide as instructed by his heart failure clinic and primary care physician. During this hospitalisation, $\mathrm{PaCO}_{2}$ was $102 \mathrm{~mm} \mathrm{Hg}$. BiPAP did not sufficiently assist and the patient was intubated. CT of the abdomen and pelvis was performed and revealed bulky confluent masses around the pancreatic head, root of mesentery and the abdominal

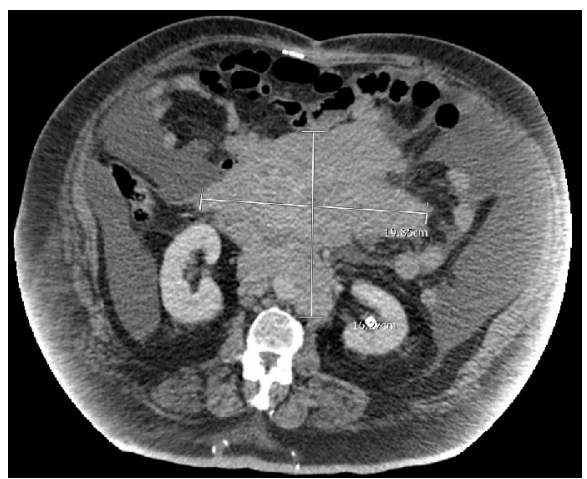

Figure 1 Bulky confluent masses around the pancreatic head, root of mesentery, and the abdominal aorta measuring approximately $20 \times 18 \times 4 \mathrm{~cm}$ with massive ascites. Cytology $\times 2$ did not show malignancy and diagnosis required a retroperitoneal core biopsy.

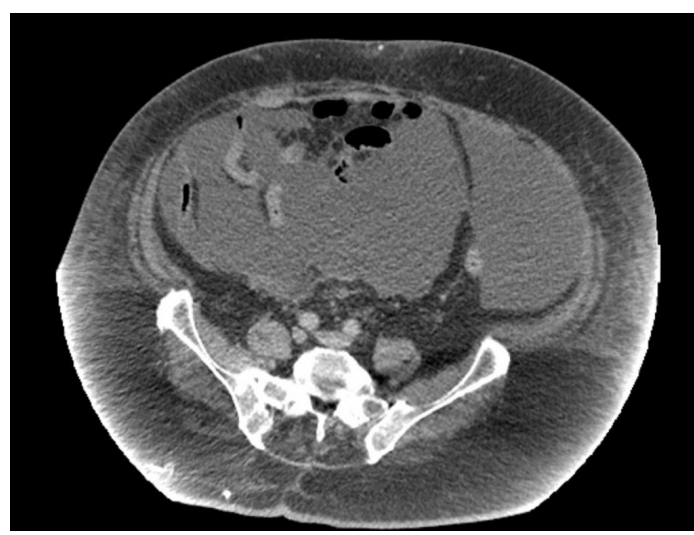

Figure 2 Massive, tense ascites. On paracentesis, $6.5 \mathrm{~L}$ of milky white fluid drained.

aorta measuring approximately $20 \times 18 \times 4 \mathrm{~cm}$ with massive ascites (figures 1 and 2).

A paracentesis was performed and $6.5 \mathrm{~L}$ of milky white fluid was drained with a triglyceride count of $2265 \mathrm{mg} / \mathrm{dL}$ (for comparison, serum triglyceride was only $206 \mathrm{mg} / \mathrm{dL}$ ), lactate dehydrogenase of 144 units $/ \mathrm{L}$, protein of $3.8 \mathrm{~g} / \mathrm{dL}$ and with cells read as $100 \%$ monocytes. Cytology of the chylous ascites was negative for malignancy on two occasions. A subsequent retroperitoneal lymph node core biopsy showed follicular lymphoma grade 1-2. The neoplastic follicles were positive for CD20, CD10, BCL2 and BCL 6. Meshworks of follicular dendritic cells were positive for CD21 and CD23. The neoplasm showed a Ki-67 proliferation fraction of $30 \%$. Flow cytometry was performed on the retroperitoneal biopsy which showed a low cellularity of $35 \%$ lymphocytes with a viability of $33 \%$. The lymphocytes analysed were mostly T-cells expressing CD5. Left iliac crest bone marrow biopsy showed lymphoma cells comprising 5\% of total marrow cellularity, the involvement of which set the lymphoma at stage IV according to the Ann Arbor staging system. The patient was treated with 5 days of dexamethasone and subsequently started on cycles of rituximab and bendamustine. Over the course of 18 days following peritoneal drain placement, peritoneal fluid drained profusely, and the patient lost $30.2 \mathrm{~kg}$ ( 4.8 stone). The patient was then discharged home with the peritoneal drain, which was removed outpatient.

At the patient's follow-up appointment in clinic, the patient was no longer hypoxic and did not require oxygen at rest nor with activity. $\mathrm{He}$ was 
sleeping better, did not critically require diuretics and felt significantly leaner and more robust.

\section{Learning points}

- There is significant evidence that Agent Orange, an herbicide used in the Vietnam War, is associated with non-Hodgkin's lymphoma, Hodgkin disease, chronic lymphocytic leukaemia (including hairy cell leukaemia and other chronic B-cell leukaemias), soft tissue sarcoma and chloracne.

- Indolent intra-abdominal malignancy can cause cardiopulmonary signs and symptoms and masquerade as other diseases. In patients with risk factors for malignancy and cardiopulmonary signs and symptoms, along with increased abdominal girth, malignancy remains on the differential diagnosis.
Contributors MSL was the senior resident who saw this patient, obtained consent and initiated work on the manuscript. CA was the junior resident who helped write the manuscript. HL-F was the attending resident who saw this patient and reviewed this manuscript.

Funding The authors have not declared a specific grant for this research from any funding agency in the public, commercial or not-for-profit sectors.

Competing interests None declared.

Patient consent for publication Not required.

Provenance and peer review Not commissioned; externally peer reviewed.

\section{REFERENCES}

1 Chang ET, Boffetta P, Adami HO, et al. A critical review of the epidemiology of Agent Orange or 2,3,7,8-tetrachlorodibenzo-p-dioxin and lymphoid malignancies. Ann Epidemiol 2015;25:275-92.

2 National Academies Press (US). Committee to review the health effects in vietnam veterans of exposure to $H$, board on the health of select $P$, Institute of $M$, National academies of sciences E, Medicine. Veterans and agent orange: update 2014. Washington (DC): National Academies Press (US), 2016.

Copyright 2019 BMJ Publishing Group. All rights reserved. For permission to reuse any of this content visit https://www.bmj.com/company/products-services/rights-and-licensing/permissions/

BMJ Case Report Fellows may re-use this article for personal use and teaching without any further permission.

Become a Fellow of BMJ Case Reports today and you can:

- Submit as many cases as you like

- Enjoy fast sympathetic peer review and rapid publication of accepted articles

- Access all the published articles

- Re-use any of the published material for personal use and teaching without further permission

For information on Institutional Fellowships contact consortiasales@bmjgroup.com

Visit casereports.bmj.com for more articles like this and to become a Fellow 